\title{
セシウムを含む廃棄物を対象とした 海面処分場に用いる遮水地盤材料に関する研究
}

\author{
村上 博紀 $1 \cdot$ 土田 孝 2 片山 遥平3 \\ 1学生会員 広島大学大学院工学研究科（干739-8527 広島県東広島市鏡山1-4-1） \\ E-mail:m132546@hiroshima-u.ac.jp \\ 2正会員 広島大学大学院工学研究院（干739-8527 広島県東広島市鏡山1-4-1） \\ E-mail:ttuchida@hiroshima-u.ac.jp \\ 3広島大学工学部（７７39-8527 広島県東広島市鏡山1-4-1） \\ E-mail:b102889@hiroshima-u.ac.jp
}

\begin{abstract}
2011年に発生した東日本大震災とその直後の福島第一原発事故によって，セシウムを含んだ廃棄物が発 生した.このような廃棄物の適正な管理処分を行う処分場として, 海面処分場に着目した. 本研究では, 海面処分場に用いる遮水材料として海成粘土にベントナイトと製鋼スラグを混合した材料に着目し，これ に対して遮水性能とセシウムに対する吸着性能の検討を室内実験により行った。遮水性能については, 海 成粘土にベントナイトを添加することで向上するが，製鋼スラグを添加した場合，大幅に低下してしまう ことが分かった。 また，セシウムに対する吸着性能については，ベントナイトを添加するにしたがい低下 したが，製鋼スラグを添加した供試体については比較的高いという結果となった。
\end{abstract}

Key Words : marine clay, bentonite, steel slag, cesium

\section{1. はじめに}

2011 年 3 月 11 日に発生した東北地方太平洋沖地震と 津波によって発生した福島第一原子力発電所の事故によ り，福島県を中心とした広範囲の地域において 2,700 万 $\mathrm{m}^{3}$ ものセシウムを含んだ災害廃棄物が発生した ${ }^{1)}$. また, 復興事業の過程で, 被災地域の除染にともなって除去し た表土，放射能レベルの高い廃棄物焼却灰，下水処理場 や河川底質に集積した放射能污泥が発生し続けている。

これらの放射性セシウムを含む廃棄物・除染発生土等は, 通常の廃棄物処分場に処分できないため仮置きとして保 管せざるを得ないがその量が増加するとともに, 被災地 の復興を進める上で大きな障害となっている. この問題 に対処するため国は中間貯蔵施設の建設を計画している が，将来的には最終処分が必要になると考えられる.

わが国では，過去に経験した大震災からの復興におい て，海面を利用した災害廃棄物の処分がなされてきた。 阪神大震災によって発生したガレキは 2,000 万トンに達 し処分場の確保が問題となったが，大阪湾広域臨海環境 整備センターが臨海部に計 1,500 万 $\mathrm{m}^{3}$ 分の処分地を提供 したことと，迅速に港湾計画を改訂して神戸港内に 450 ha の災害ガレキ埋立用地が確保されたことにより，比 較的短期間で処分が終了している ${ }^{2}$. わが国における管
理型廃棄物処分場は陸域に設置するタイプと海面に立地 するタイプがあり，海面処分場は，1箇所で 100 万 $\mathrm{m}^{3}$ か ら 1,000 万 $\mathrm{m}^{3}$ 以上の容量を有する, 船舶を用いることで 廃棄物の運搬過程で発生する問題を軽減できるという長 所がある. 一方で, 波浪, 高潮, 地震, 津波などの厳し い外力が作用するため構造安全性に十分留意する必要が ある.また，海底に厚い粘土層が堆積している場合は海 底地盤自体が底面遮水層となるが，海底が砂質地盤の場 合は底面遮水を行う必要があり,このための遮水地盤材 料の研究が行われてきた 3 月4,5.

本研究で対象とする海面処分場では，セシウムで污染 された廃棄物を対象とする。そそのため，廃棄物を処分場 内に投入寸る際に発生寸る余水を処分場外一放流寸るこ とは困難であることが予想される，そこで本研究では， 余水を発生させないために, あらかじめ処分場内の水位 を低下させた上で，廃棄物を投入すると想定した．この 条件では, 内外水位差により遮水層に大きな揚圧力が作 用するのでカウンターウエイトとして覆土が必要である. しかし，覆土層が厚くなると処分場の容積が減少するの で遮水層の単位重量が大きいことが望ましい.これに対 抗するために，単位重量の大きな遮水材料が必要である.

筆者らの検討では，海成粘士にベントナイトを添加し た場合，透水係数を減ずることできるという結果が得ら 
れれているの。 また，渡部らは透水係数の低い粘土に砂 を混合する一連の実験を行い，砂分混合率がある範囲内 であれば透水係数はほとんど変化しないことを報告して いる》。.これらの既往の研究報告を参考にして, 本研究 では単位重量の大きな遮水地盤材料として, 海成粘土に ベントナイトと単位重量の大きな製鋼スラグを添加した 材料について遮水材料としての適用性を検討することと した．海成粘土に製鋼スラグを透水係数が増加しない範 囲で添加した場合, 以下のような効果が期待される.

1) 圧縮性が減少するため, 圧密係数が増加する. 遮水 層の圧密が早期に進行し，有効圧密応力増加による 透水係数の低下を期待できる.

2）製鋼スラグ添加により，遮水材料の単位重量が増加 し，覆土層の厚さを抑えることができる．例えば， 内外水位差が $5 \mathrm{~m}$, 遮水層厚を $4 \mathrm{~m}$ とし, 遮水材料 の単位重量が $13.5 \mathrm{kN} / \mathrm{m}^{3}$ の場合と $16.5 \mathrm{kN} / \mathrm{m}^{3}$ の場合を

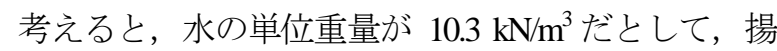
圧力に対する自重の不足は，それぞれ $38.7 \mathrm{kN} / \mathrm{m}^{3}$ と $26.7 \mathrm{kN} / \mathrm{m}^{3}$ となり, 必要覆士厚に大きな差が生じる.

本研究では，これらの効果の実現可能性を検討するた めに, 海成粘土に対し, 様々な配合量でベントナイトと 製鋼スラグを配合し，遮水性能とセシウムに対する吸着 性能について検討した.

\section{2. 遮水性能の検討}

\section{(1) 試験方法}

本研究では海成粘土として徳山港粘土, ベントナイト としてワイオミング産ベントナイト (以後, ベントナイ ト），製鋼スラグを用いた．表-1 にそれぞれの物性值 を示す．製鋼スラグについては，0.85〜2mm に粒度調整 し，水洗いを行って細粒分を十分に除去したものを用い た. 表-2 に本研究で用いた供試体の配合パターンを示 す. 表-2 のベントナイト添加量とは液性限界の 1.5 倍の 含水比の徳山港粘土 $1 \mathrm{~m}^{3}$ に対する添加量である. また, 製鋼スラグの体積比とは粘土粒子（ベントナイト粒子も 含む）体積に対する乾燥体積比である.

遮水性能の検討については，段階載荷圧密試験を実施 し, 試験から求まる透水係数から評価した。.まず，それ ぞれの供試体の含水比を液性限界の 1.5 倍程度に調泥し た. その後, 直径 $60 \mathrm{~mm}$, 高さ $20 \mathrm{~mm}$ の圧密リングにス ラリー状の供試体を充填した，載荷応力については，応 力増分比 $\Delta p / p=1$ で, 圧密応力 4.9 627.2 kPa の計 8 段階の 段階載荷を行った。 また, 透水係数については式(1)を 用いて算出した.

$$
k=c_{\mathrm{v}} \cdot m_{\mathrm{v}} \cdot \gamma_{\mathrm{w}}
$$

ここで $c_{\mathrm{v}}$ は圧密係数, $m_{\mathrm{v}}$ は体積圧縮係数, $\gamma_{\mathrm{w}}$ は水の単 位重量である。
表-1 用いた試料の物性值

\begin{tabular}{c||c|c|c}
\hline 試料 & 徳山港粘土 & $\begin{array}{c}\text { Dイオミング産 } \\
\text { ベントナイト }\end{array}$ & 製鋼スラグ \\
\hline 土粒子密度 $\rho_{\mathrm{S}}\left[\mathrm{g} / \mathrm{cm}^{3}\right]$ & 2.616 & 2.898 & 3.44 \\
\hline 液性限界 $w_{L}[\%]$ & 110.6 & 510.6 & - \\
\hline 塑性限界 $w_{\mathrm{P}}[\%]$ & 40.0 & 44.0 & - \\
\hline 塑性指数 $I_{\mathrm{P}}$ & 70.6 & 466.6 & - \\
\hline
\end{tabular}

表-2 配合パターン

\begin{tabular}{|c|c|c|}
\hline 試料名 & 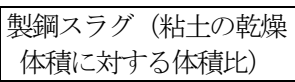 & $\begin{array}{c}\text { ベントナイト添加量 } \\
\text { (粘士スラリー1mあり }\end{array}$ \\
\hline T0 & \multirow{6}{*}{ 無添加 } & 無涯加 \\
\hline $\mathrm{T} 25$ & & $25 \mathrm{~kg} / \mathrm{m}^{3}$ \\
\hline T50 & & $50 \mathrm{~kg}^{3}{ }^{3}$ \\
\hline $\mathrm{T} 75$ & & $75{\mathrm{~kg} / \mathrm{m}^{3}}$ \\
\hline T100 & & $100 \mathrm{~kg}^{3} \mathrm{~m}^{3}$ \\
\hline T150 & & $150 \mathrm{~kg}^{3} \mathrm{~m}^{3}$ \\
\hline ToS93 & $93 \%$ & 無添加 \\
\hline Tos50 & \multirow{3}{*}{$50 \%$} & 無添加 \\
\hline T25S50 & & $25 \mathrm{~kg}^{3} \mathrm{~m}^{3}$ \\
\hline T50S50 & & $50 \mathrm{~kg} / \mathrm{m}^{3}$ \\
\hline TOS25 & \multirow{2}{*}{$25 \%$} & 無添加 \\
\hline T50S25 & & $50 \mathrm{~kg} / \mathrm{m}^{3}$ \\
\hline
\end{tabular}

\section{(2) 試験結果}

図-1 に透水係数 $k$ と平均圧密応力 $\bar{p}$ の関係を示寸. 徳山港粘土にベントナイトを添加するに従い, 透水係数 が低下（遮水性能が向上）していることがみてとれる. これは, ベントナイトが膨閏し, 徳山港粘土の間隙を充 填したためと考えられる. 一方, 徳山港粘土に製鋼スラ グを添加した場合, 透水係数が大幅に増加（遮水性能が 低下）していることが確認できる．特に製鋼スラグを体 積比で 93\%添加した（T0S93）場合, 徳山港粘土のみの 供試体（T0）に比べて 10 倍程度透水係数が大きくなる という結果となった。これは製鋼スラグ添加によって, 水みちが存在する構造が形成され, 透水性が向上したた めだと考えられる. しかし，この点については SEM や ポロシメーターを用いた微視構造から確認する必要があ る.これについては第 3 章で詳しく述べる. また，徳山 港粘土に製鋼スラグを添加した場合でも, ベントナイト を添加することである程度, 透水係数を減ずることがで きることが確認された.

図-2 に圧密係数 $c_{\mathrm{v}}$ と平均圧密応力 $\bar{p}$ の関係を示寸. まず，徳山港粘土にベントナイトを添加した供試体につ いては, ベントナイトの添加量が多いほど圧密係数が小 さいことがみてとれる。これは, ベントナイトの膨閏効 果により, 供試体内の間隙に含まれる自由水が減少した ためだと考えられる. 一方, 徳山港粘土に製鋼スラグを 添加した供試体については，製鋼スラグの添加量が多い ほど圧密係数の值が大きいことがみてとれる.これは図 -1 でも確認されたように，製鋼スラグ添加により透水 性が向上寸ることで，排水速度が向上したためだと考え られる。

図-3に間隙比 $e$ と圧密応力 $p$ の関係を示す. 徳山港粘 


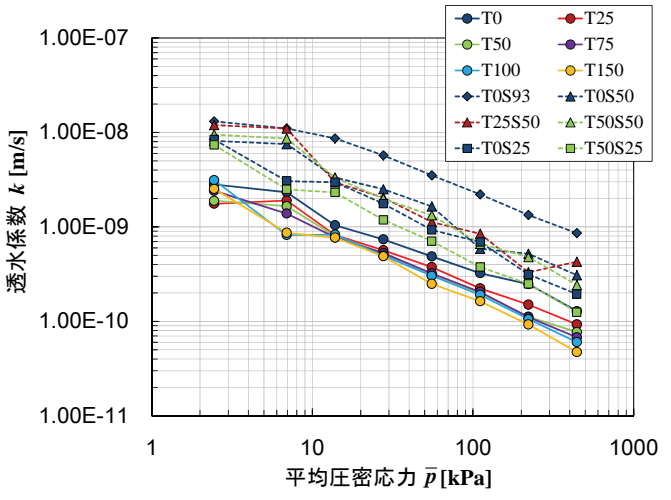

図-1 $k-\bar{p}$ 曲線

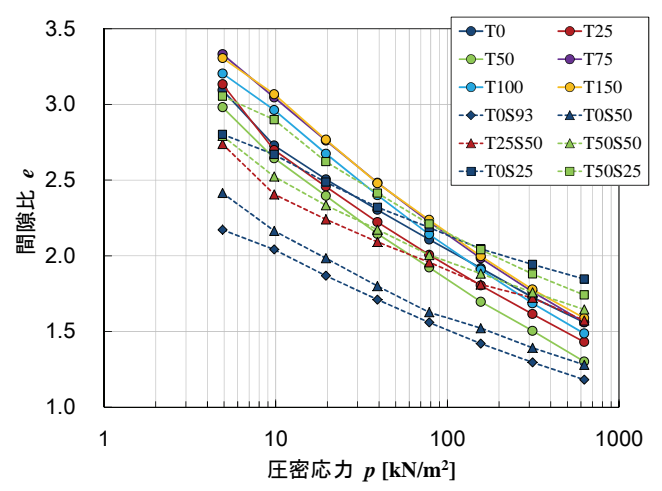

図-3 e-log $p$ 曲線

土にベントナイトを $50 \mathrm{~kg} / \mathrm{m}^{3}$ までの添加量であれば，間 隙比を減ずる効果が確認できた。しかし，ベントナイト を $75 \mathrm{~kg} / \mathrm{m}^{3}$ 以上添加した場合は, 逆に間隙比が大きくな っていることがみてとれる.これは，ベントナイトが膨 潤し，ベントナイト粒子の粒径が大きくなることで，間 隙が生じや寸い状況になったためと考えられる．一方， 製鋼スラグを添加した供試体については，製鋼スラグを 添加していない供試体に比べて $e-\log p$ 曲線の傾きが緩 くなっていることがみてとれる。これは徳山港粘土に圧 縮性の非常に低い製鋼スラグを添加することで，供試体 の圧縮性が低下してしまったためだと考えられる.

図-4 に湿潤単位重量 $\gamma_{\mathrm{t}}$ と圧密応力 $p$ の関係を示寸。徳 山港粘土にベントナイトを添加しても，供試体の湿潤重 量に大きな変化はみられなかった，一方，徳山港粘土に 製鋼スラグを添加した場合，大幅に湿潤単位重量が増加 していることがみてとれる. これより，単位重量の大き な遮水材料という点では, 製鋼スラグの添加は有効であ ることが確認された.

\section{3. 製鋼スラグを含んだ供試体の微視構造の把握}

\section{(1) 試験方法}

第 2 章の圧密試験結果でも述べたように，徳山港粘土 に製鋼スラグを添加した場合，透水係数が大幅に増加す るという結果となった．そこで，この原因を究明するた めに製鋼スラグを含んだ供試体の微視構造の把握をポロ

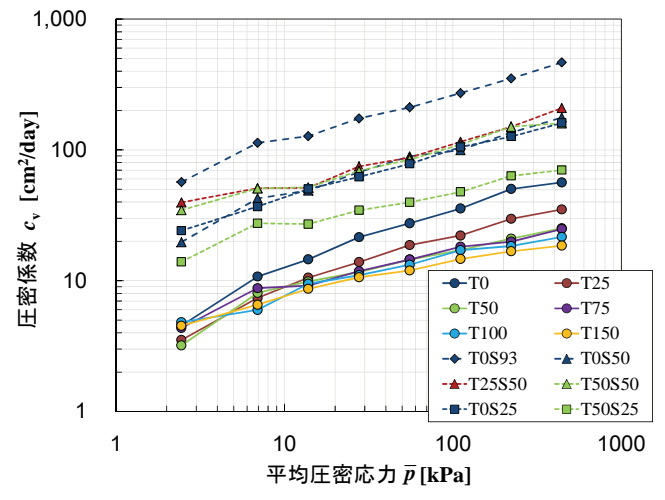

図-2 $c_{\mathrm{v}}-\bar{p}$ 曲線

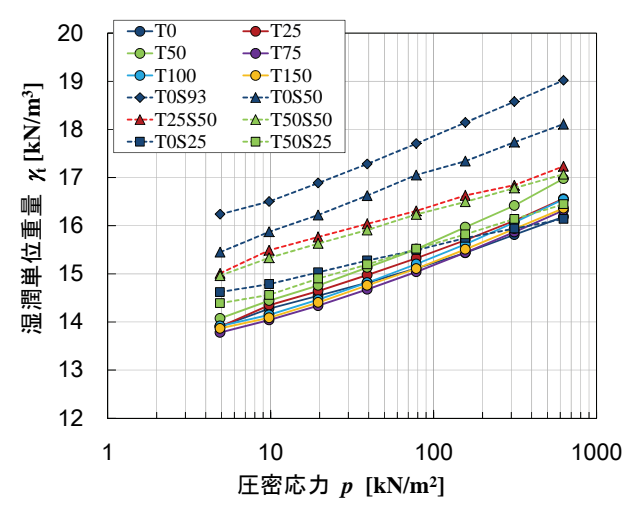

図-4 $x$ - $\log p$ 曲線

シメーターと走査型電子顕微鏡（以後, SEM）により行 った. 本研究では代表として表-2 に示した T0S93,

T0S50, T0S25, T50S50 に対し微視構造の検討を行った。

まず，1つの配合パターンに対し，第 2 章の段階載荷

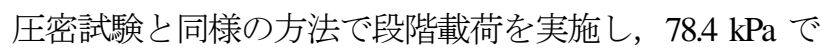
圧密完了したものと, $627.2 \mathrm{kPa}$ で圧密完了したものの計 $2 つ の$ 試料を用意した。 この試料を， $5 \times 5 \times 30 \mathrm{~mm}$ 程度 にワイヤーソーで切り出し, 液体窒素て瞬間凍結させ, 真空凍結乾燥器内で十分乾燥させた. その後, ポロシメ ーター用，SEM 用に試料を整形した。ポロシメーター では試料内に水銀を圧力を変化させながら注入すること によって得られる注入圧力と注入量の計測結果をもとに 試料の間隙分布を把握した. SEM では, 切り出した試 料をアルミ製のマウントに伝導性の接着剤で固定し，試 料表面に金を蒸着させて, 試料表面の観察を行った.

\section{(2) 試験結果}

図-5，図-6 にそれぞれ $78.4 \mathrm{kPa} ， 627.2 \mathrm{kPa}$ で圧密した 供試体の間隙容積頻度曲線, 間隙容積分布曲線を示す.

図-5 を見ると, T50S50 を除き, 圧密が進行するにした がって，ピーク時の間隙直径と間隙容積が減少している ことが分かる．また，図-6 を見ても，圧密が進行する ことで曲線が左側にシフト, つまり供試体の間隙直径が 小さくなっていることが分かる. これは, 圧密進行に伴 って, 供試体の構造が密実になったためだといえる.

T50S50 は圧密応力 $78.4 \mathrm{kPa}$ での間隙容積が他の供試体に 比べ一番小さかった. これは, ベントナイトの間隙充填 


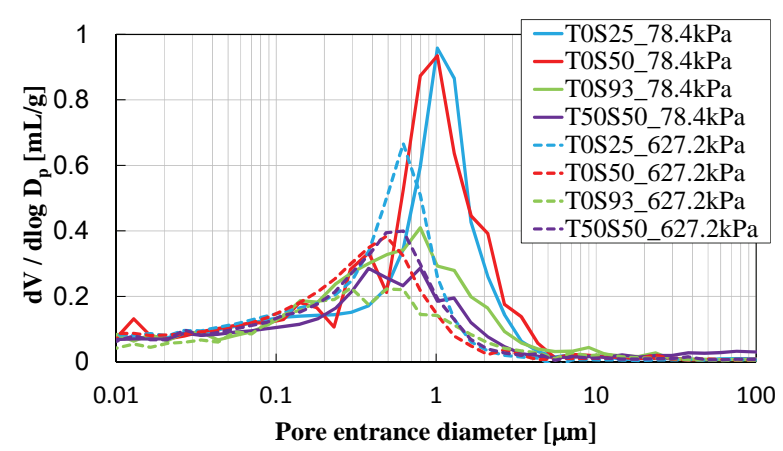

図-5 間隙容積頻度曲線

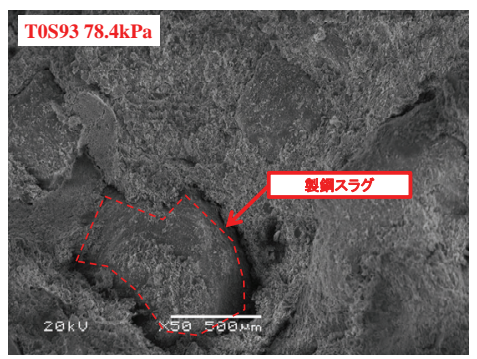

図-7 T0S93 の SEM 画像（左 : 圧密応力 $78.4 \mathrm{kPa}$, 圧密応力 $627.2 \mathrm{kPa}$ )

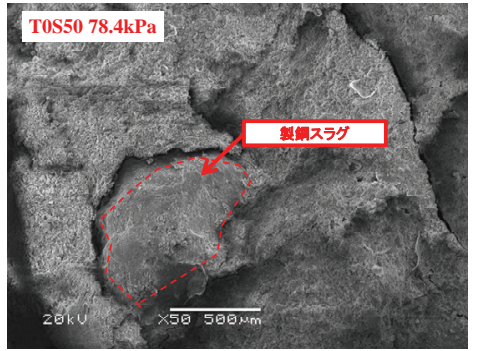

図-8 TOS50 の SEM 画像（左 : 圧密応力 $78.4 \mathrm{kPa}$ ，圧密応力 $627.2 \mathrm{kPa}$ )

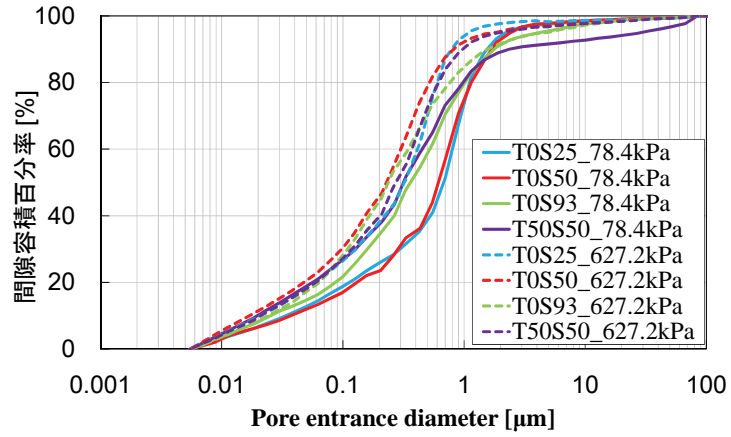

図-6 間隙容積分布曲線
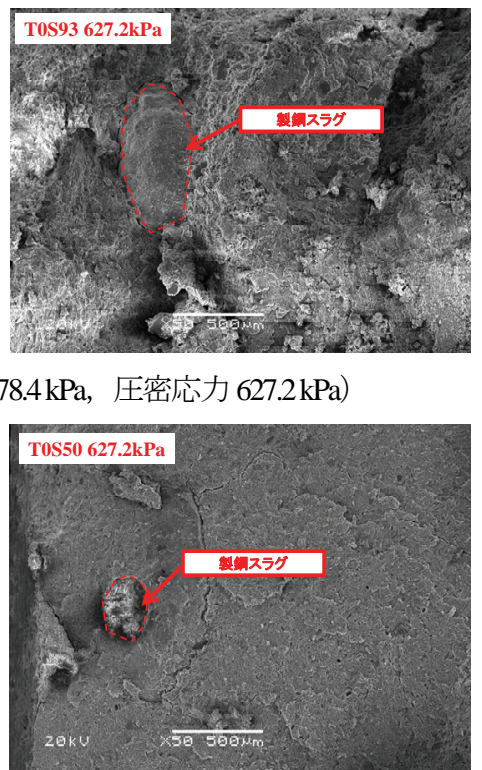

効果によるものと考えられる．しかし，圧密応力 627.2 $\mathrm{kPa}$ になると, 間隙容積のピーク值が増加している。こ の原因については不明だが，ベントナイトの膨閏効果が 要因として考えられる. 一方，T0S93についても T50S50 と同じ傾向がみられた。これは製鋼スラグ添加によって, 圧縮性が低下し，密実になりにくかったためだと考えら れる。

次に SEM で観察したそれぞれの供試体の微視構造に ついて考察する. T0S93（図-7）については，78.4kPa で の圧密完了時において，製鋼スラグ周辺に大きな間隙が 発生していることが確認できる.また， $627.2 \mathrm{kPa}$ での圧 密完了時でも，若干ではあるが製鋼スラグ周辺の間隙が 残つている.

次に製鋼スラグの添加量を少なくした T0S50（図-8） をみると, $78.4 \mathrm{kPa}$ での圧密完了時に，製鋼スラグ周辺 に大きな間隙が発生していた。 しかし，圧密圧力 627.2 $\mathrm{kPa}$ では製鋼スラグ周辺の間隙はほとんどみられなかっ た.これは，図-5，図-6において，圧密よる間隙体積の 減少が比較的大きかったことと一致している.

図-9 は T0S25 の SEM 画像である. 他に供試体に比べ, $78.4 \mathrm{kPa}$ での圧密完了時であっても, 製鋼スラグ周辺の
間隙が少ないことが分かる．また， $627.2 \mathrm{kPa}$ での圧密完 了時では，構造がさらに密実になっていることが確認 できる.この結果についても, 図-5, 図-6で得られた, 間隙容積の減少量が比較的大きかったという結果と一 致する.

次にベントナイトと製鋼スラグを添加した試料の微視 構造について検討する. 図-10 は T50S50 の SEM 画像で ある. 圧密圧力 $78.4 \mathrm{kPa}$ における画像では製鋼スラグ粒 子を明瞭に見いだすことができなかったが，粘土部分を みても他の供試体と比べて構造が密実になっていること が伺われ，ベントナイトの間隙充填効果が表れている. 圧密圧力 $627.2 \mathrm{kPa}$ の画像では製鋼スラグ周辺に間隙が 残っていることが観察されるが，図-7,図-8 に比べると， 間隙は充填されている.

以上の結果より，製鋼スラグ粒子の周辺に発生してい た間隙の存在が透水係数が大幅に増加した原因の 1 つと して考えられる. また，一般に製鋼スラグを粘土スラリ 一と混合すると固化が進行するがこれはスラグ中の Ca と粘土中の $\mathrm{Al}$ や $\mathrm{Si}$ との水和反応によるものとされてい る ${ }^{8)}$. この固化による影響も，製鋼スラグ周辺の間隙形 成の原因の 1 つと考えられるが，この点については，今 

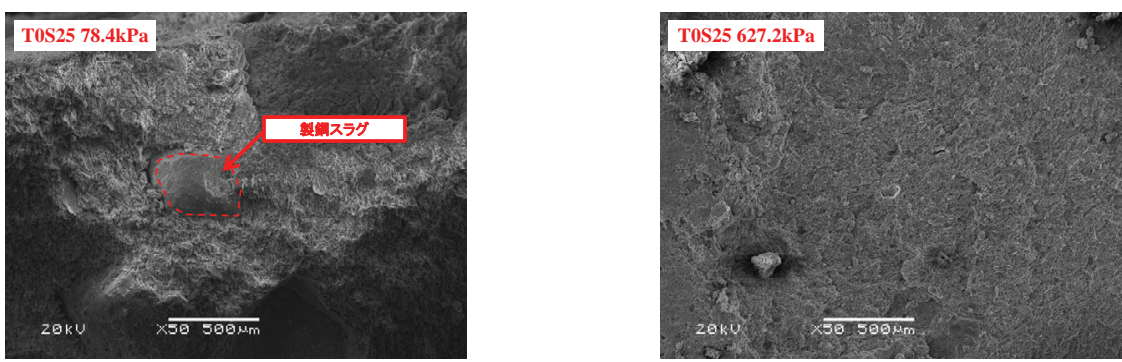

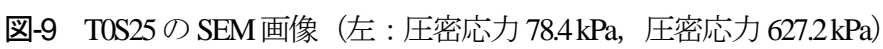
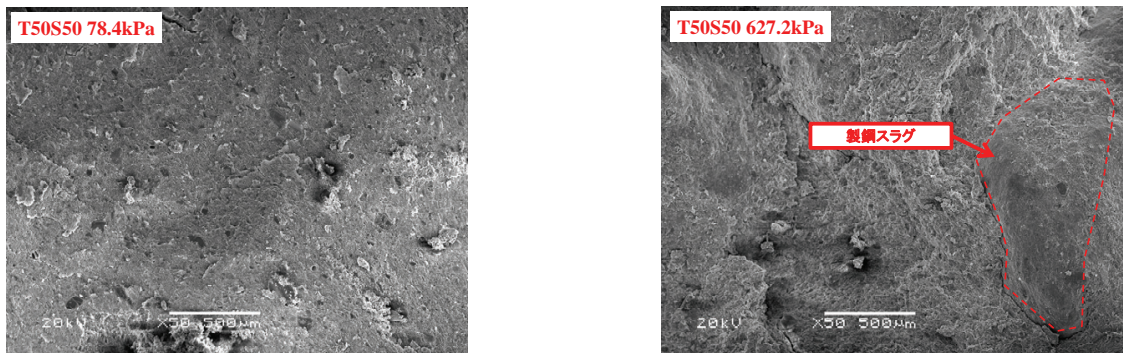

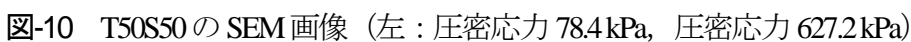

後さらに検討する必要がある.

\section{4. セシウムに対する吸着性能の検討}

\section{(1) 試験方法}

本研究では，セシウムに対する吸着性能の検討として, 圧密通水試験（カラム試験）を実施した．図-11 に本研 究で用いた装置の概略図を示寸。本研究では通水時間短 縮のために高さ $10 \mathrm{~mm}$ ，直径 $60 \mathrm{~mm}$ の圧密リングを使用 した．また，試験を実施した供試体は表-2 に示した T0, T25，T75，T150，T50S50 である。供試体の形成につい ては，段階載荷圧密試験と同様にスラリー状態のまま圧 密リングに空気が混入しないように投入した. その後, 試験機を設置し，応力増分 $\Delta p / p=1$ で $4.9 \mathrm{kPa}$ から $19.6 \mathrm{kPa}$ まで段階載荷を行った。圧密圧力 $19.6 \mathrm{kPa}$ での圧密終了 後, 圧密排水によって満たされた載荷板内部の水を二重 円筒管により $30 \mathrm{ppm}$ セシウム溶液と入れ替えた。 その 後，二重円筒管に空気圧 $19.4 \mathrm{kPa}$ を常に与え，図-11 の 矢印方向の通水経路で供試体にセシウム溶液を通水させ た．供試体に計 $300 \mathrm{~mL}$ のセシウム溶液が通水した時点 で試験を終了した。また，供試体にセシウム溶液が $10 \mathrm{~mL}$ 通水するごとに，透過液を採取し，原子吸光分析 機により濃度測定を行った．圧密通水試験による吸着性 能については，供試体を通過し，漏出したセシウムの濃 度と PVF の関係から行った。 PVF とは供試体中の間隙 水が何回入れ替わったかを表しており，式(2)のように 計算できる.

$$
P V F=\frac{\Sigma V_{\mathrm{c}}}{V_{\mathrm{v}}}
$$

ここで， $\Sigma V_{\mathrm{c}}$ は安定セシウム溶液累積通水体積， $V_{\mathrm{v}}$ は 供試体の間隙体積である。

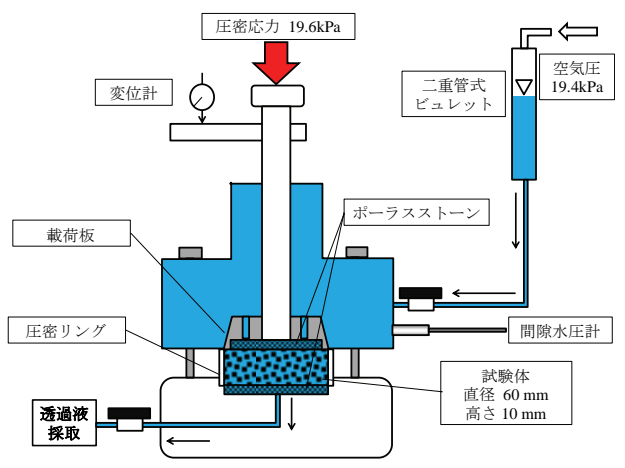

図-11 圧密通水試験装置

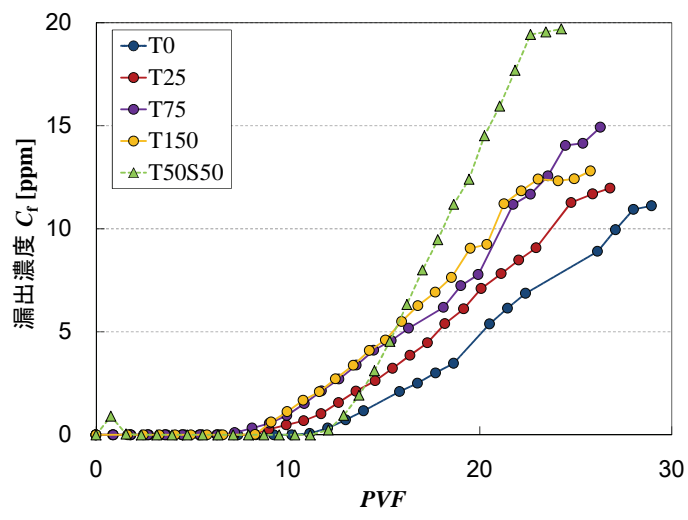

図-12 $C_{\mathrm{f}}-P V F$ 曲線

\section{(2) 試験結果}

図-12 に圧密通水試験から得られた安定セシウムの漏 出濃度 $C_{\mathrm{f}}$ と $P V F$ の関係を示寸. 図より徳山港粘土に心゙ ントナイトを添加することで，安定セシウムが漏出し始 める PVF が小さくなっていることがわかる。これより， 徳山港粘土にベントナイトを添加することで, 吸着性能 が低下したといえる。これは液性限界の大きなベントナ イトを添加寸ることで供試体の間隙体積が大きくなり， (2)式より，小さい PVF の值でセシウムが漏出したため と考えられる．また，製鋼スラグを添加した供試体につ 
いては，安定セシウムが漏出し始める PVF が比較的大 きかった（吸着性能が高かった）が，漏出後の濃度増加 勾配が他の供試体に比べて一番大きいことが分かった. これは，SEM で確認されたように，T50S50 の場合にも， $19.6 \mathrm{kPa}$ での圧密完了時において製鋼スラグ周辺の間隙 が発生し，安定セシウム溶液が漏出しやすい構造であつ たためと考えられる.

\section{5. 結論}

1) 海成粘土・ベントナイト混合材料に製鋼スラグを添 加すると，供試体の単位重量は大きくなったが，透 水係数は最大で 10 倍程度増加するという結果が得ら れた．また，製鋼スラグを添加した場合でも，ベン トナイトを添加することで, ある程度透水係数の増 加を抑えることできるが，やはり 2 倍程度は透水係 数が増加することが分かった。この結果は，砂を混 合したときの渡部らの既往の研究と大きく異なって いる.

2）製鋼スラグの添加によって透水係数が増加した原因 を検討するため，微視構造の観察と間隙径分布の測 定を行った。その結果，製鋼スラグ粒子の周辺に大 きな間隙が観察された。この間隙が透水係数増加の 原因と考えられる。間隙が発生した理由として，密 実になりにくいこと，または製鋼スラグと粘土との 化学反応およびそれによる固化の影響が考えられる が，今後さらに検討が必要である.

3）製鋼スラグを配合した材料について圧密通水試験を 実施し，セシウムに対する吸着性能の検討を行った。 その結果，製鋼スラグを配合していない供試体に比 べて安定セシウムが漏出し始める PVF（間隙水の入 れ替わり回数）は比較的大きかったが，漏出後の濃 度増加率が増加するという結果となった。

4) 今回の実験結果では，製鋼スラグ混合による効果を 達成できなかった．今後は製鋼スラグ以外に，砂や ゼオライトなどを混合した場合についても検討を行 い, 十分な遮水性能, セシウムに対する吸着性能, 適
切な単位重量を有する遮水材料の開発を行う。

謝辞 : 本研究は，環境省の平成 25 年度環境研究総合推 進費 (補助金) 課題名「放射能で污染された廃棄物を対 象とした海面最終処分場に関する研究」によって実施し たものである．また，本研究を共同で実施している渡部 要一博士（独)港湾空港技術研究所），上野一彦博士

（五洋建設(株)技術研究所）には本論文をまとめる上で 貴重なご指摘をいただいた，関係各位に心より感謝いた します。

\section{参考文献}

1)環境省廃棄物・リサイクル対策部 : 災害廃棄物等処理の 進捗状況（3 県沿岸市町村（避難区域を除く）），pp.1, 2013.

2) 土田孝, 水上純一, 菊池喜昭, 吉野博之 : 阪神・淡路大 震災におけるガレキの処理・活用に関する調査と考察, 港湾空港技術研究所資料, No.0899, 1998.

3) 山田耕一，上野一彦，羽田晃，土田孝，渡部要一 : 変 形追随性遮水材料を用いた管理型海面廃棄物最終処分場 の新しい遮水構造の提案, 海洋開発論文集, pp.77-82, 2002.

4) 上野一彦, 山田耕一，渡部要一：管理型海面廃棄物処分 場に用いる浚渫粘土を主材料とした土質遮水材料の提案, 土木学会論文集 G，Vol.64，No.2，pp.177-186， 2008.

5) 川崎隆広, 山田耕一, 上野一彦: 海面処分場における土 質遮水材料の施工事例，地盤と建設，Vol.27， No. 1, 地 盤と建設，pp.187-194， 2009.

6) 村上博紀, 土田孝, 安部太紀 : 放射性セシウムで污染さ れた廃棄物を対象とした海面処分場に用いる遮水地盤材 料の研究，第 10 回環境地盤工学シンポジウム発表論文集， pp.311-318, 2013.

7) Watabe, Y., K, Yamada and K, Saitoh : Hydraulic conductivity and compressibility of mixtures of Nagoya clay with sand or bentonite, Geotechnique, Vol .61, No. 3, pp.211-219, 2011.

8) (社)日本鉄鋼連盟 : 転炉系製鋼スラグ海域利用の手引き, pp.24-28, 2008.

\section{Study of Geo-material Used for Coastal Disposal Facilities for Waste Including Cesium}

\section{Hiroki MURAKAMI, Takashi TSUCHIDA and Youhei KATAYAMA}

A large amount of waste contaminated by radioactive cesium was released from Fukushima daiichi nuclear power plant due to the great east japan earthquake. The objectives of this study were to examine the permeability characteristics and water adsorption properties of a geo-material . In this study, Tokuyama clay was mixed with different proportions of bentonite and steel slag. Results revealed that the coefficient of permeability decreases with the increase of bentonite and that increases with the adding of steel slag. The adsorption performance was found to be decreased with the adding of bentonite. In contrast, the adsorption performance was comparatively increased with the adding of steel slag. 